\title{
Impact of Team Goal Orientation and Information Exchange on Creativity and Innovation in Advertising Creative Teams of Pakistan
}

\begin{abstract}
Atif Bilal ${ }^{1}$, Wisal Ahmad ${ }^{2}$
Abstract

The main objective of the study is to investigate the impact of team goal orientation and information exchange on creativity and innovation in advertising creative teams of Pakistan. The data is collected from 70 teams and 436 employees of the advertising agencies in Pakistan and analyzed statistically using MEDTHREE analysis. The findings indicate that team goal orientation induces information exchange among team members, which leads to organizational innovation through team creativity in the advertising agencies of Pakistan. The mediation analysis of the data shows that for the innovation it is necessary that information exchange and creativity must exist at team level. The study may be useful for the managers of the advertising agencies of Pakistan to deal with the studied factors for the enhancement of creative thinking and innovation in the advertising agencies of Pakistan.
\end{abstract}

Keywords: Goal orientation, information exchange, creativity, innovation.

\section{Introduction}

The interest of understanding creativity and innovation in business organizations has increased in the last two decades (Perry-Smith \& Mannucci, 2017). Organizations these days are very much concerned to know how to enhance the generation (creativity) and practical implementation (innovation) of unique and novel ideas (Zhou \& Shelley, 2008). Recent studies, (e.g., Hirst, Zhu, \& van-Knippenberg, 2009; Bilal \& Ahmed, 2015) have embarrassed the goal orientation theory in order to understand creativity and innovation. These studies have identified the relationship of goal orientation with creativity and established that there is a positive relationship between the individual goal orientation and individual creativity. Another study (Gong, Cheung, Wang, \& Huang, 2012) has shown the positive relation of goal orientation with team creativity, but these studies have not investigated the relationship of goal orientation and creativity with the innovation-without which creativity has no value.

1 Assistant Professor, SZABIST, Islamabad. atifbilal@live.com

2 Associate Professor, Institute of Business Studies, KUST, Pakistan.dr.wisal.kust@gmail.com

\begin{tabular}{ll} 
ARTICLE HISTORY & \\
7 July, 2018 Submission Received & 8 Nov, 2018 First Review \\
\hline 12 Nov, 2018 Second Review & 30 Jan, 2019 Third Review \\
\hline 10 Feb, 2019 Accepted &
\end{tabular}


The team learning goals can be taken as the urge to learn new things, gaining positive outcomes, to compete and outperform the other teams and to avoid the failure in the projects (Bunderson \& Sutcliff, 2003; Mehta \& Mehta, 2018). The information exchange is the exchange of ideas, thoughts, knowledge and other work related information among organizational members (Johnson et al., 2006). The creativity is a creation of new and novel ideas which are important for all types of organizations (Simonton, 2018). The innovation is the implementation of the creative ideas in practice - newness/ novelty of the ad for the present study.

The literature on team orientation and information exchange reflects a positive relationship between the variables (Gong, Kim \& Lee, 2012; Guan, Xie, \& Huan, 2018). It has been seen that if the goal orientation is high among members of a team, it can lead to a higher level of information exchange within the organization (Kozlowski \& Klein, 2000; Rousseau, 1985).

In the same zeal some studies also saw the mediating role of team creativity and information exchange (Bilal \& Ahmed, 2015; Mesmer-Magnus \& De-Church, 2009) between team goal orientation and organizational innovation. The information exchange and the knowledge sharing are interrelated and are the foremost requirement to enhance creativity in teams (Guan, Xie, \& Huan, 2018; Smith, Collins, \& Clark, 2005). The information exchange may be taken as the exchange of ideas, thoughts, knowledge and other work related information with team members (Johnson et al., 2006), which has a great impact on the individual creativity of the employees (Ramos, Figueiredo, \& Pereira-Guizzo, 2018; Van-Knippenberg et al., 2004). The team learning goals can be taken as the urge to learn new things, gaining positive outcomes, to compete and outperform the other teams and to avoid the failure in the projects (Bunderson \& Sutcliff, 2003). Team creativity can be referred as the generation of useful, new and unique ideas by the team, whereas the organizational innovation is the successful implementation of these creative ideas for the betterment of the organization (Sutcliff, 1998; Bilal, Ahmad, \& Majid, 2018). Though the main focus of the study is organizational innovation, yet the team creativity and its impact on organizational innovation is an area of investigation.

The creativity is a creation of new and novel ideas which are important for all types of organizations (Liu, Gong, Zhou, \& Huang, 2017). The main purpose of creating these ideas is to bring positive change and to produce new products or processes within the organizations. Levitt (1963, p. 79) beautifully clarified the relationship between the creativity and innovation by saying that "ideas are useless unless used". Creativity is the creation and innovation is the implementation of the new ideas (Amabile, 2016). Therefore, creativity can only be useful for an organization if it is converted to tangible new products or processes. Many organizations have the culture and mechanisms to 
foster creativity among the employees, yet a few fail to convert these unique ideas to bring innovation in the organization. The creativity and innovation puzzle has been a longstanding issue for many researchers (e.g., Guan, Xie, \& Huan, 2018; Perry-Smith, \& Mannucci, 2017; Ramos, Figueiredo, \& Pereira-Guizzo, 2018; Schumpeter, 1942; Simonton, 2018). Amabile (1996) and Oldham and Cummings (1996) argued that creativity is the making of new ideas and innovation is the process of implantation of these ideas to make a unique product, process or a practice. The same has been shared by a number of studies, for example Amabile (2017) and Gong et al. (2012). The body of knowledge in the form of discussing studies provides a significant insight about the importance of creativity for the innovation within the organizations.

The advertising agencies make adverts and ideas, which are the key to making effective advertisements (Taylor, Taylor, \& Hoy, 1996). There is no second opinion that creativity and innovation are the soul of an advertisement and they may look different because of the novelty and uniqueness of new ideas and their implementation (Cunado Nixon, \& Carter, 2003). The advertising agencies in Pakistan attempt to follow the trends of creativity and innovation, which are being adopted globally (Antonietti \& Colombo, 2017). They are gradually moving towards creativity and innovation because of the dynamic business environment. It is argued that information technology wave has created intense competition in the corporate world, particularly in the advertising agencies and forced them to become more creative and innovative for their survival. The ads are made by the teams consisting of four to ten members having separate job descriptions, yet they need to share ideas when it comes to creative ads (Taylor, Taylor, \& Hoy, 1996). Therefore, to answer the central research question, the teams from the different advertising agencies of Pakistan are selected for the study.

For the present study, the goal orientation has been taken as a composition of three dimensions, i.e., (i) the learning goal (ii) performance goal and (iii) performance avoidance goals. The same typology has been used by a number of previous researchers (Hirst, van-Knippenberg, Chen, \& Sacramento, 2011). The goal orientation is present at the team level if the team members are sharing information, helping each other for team decision making, strive to learn new things and to come up with better decision making with collaboration among the members (Bunderson \& Sutcliffe, 2003). The situational factors are very important to stimulate the goal orientation, which includes the type of leadership, the goal setting of the team and the performance evaluation of the members (Gully \& Phillips, 2005). Most of the times the team members face the same situations and consult each other to interpret the situation for which they require sharing of information. As team members integrate into a squad, they forge a shared goal perception in the contour of a team goal orientation (Bunderson \& Sutcliffe, 2003). In the present study it is argued that goal orientation facilitates the 
information exchange among team members which promote team creativity that eventually becomes the stepping stone for organizational innovation. Therefore, the main research question of the study is - does team goal orientation through information exchange induces creativity and innovation in advertising teams of Pakistan?

The previous literature (Bilal et al., 2018; Hirst et al., 2009) looked into the relationship of goal orientation with creativity at individual level. The present study has contributed towards the previous work by examining the relationship at team level. As this study's investigations suggest a direct and the indirect effect of the team goal orientation with creativity, therefore, the study by Hirst et al. (2009) and Bunderson and Sutcliffe (2003) in combination are consistent with our examination. Another important study by Gong et al. (2012) indicates that team goal orientation is related to team creativity with mediating mechanism of information exchange. The present research furthers the previous findings by including the innovation as dependent variable, without which creativity does not have much value. Although, prior research talks about the relationship of information exchange and creativity in different organizational contexts, this study has empirically examines the relationship in the advertising agencies of Pakistan.

The componential model of creativity (Amabile \& Pratt, 2016) suggested that in order to be creative, the exchange of information, new ideas and knowledge is required at the workplace. The team goal orientation and the information exchange among team members are closely related to the suggestion of componential model of creativity for creativity and innovation. As the arguments of this paper also suggest that for creativity and innovation, the team goal orientation and information exchange are necessary. Therefore, a noteworthy contribution of this research is the extension of componential model of creativity. The study is an extension of team goal orientation theory and departs from previous studies by analyzing the sequential mediation of information exchange and creativity between the relationship of goal orientation and innovation.

\section{Literature Review}

\subsection{Goal orientation and information exchange}

Sharing of information has always been an effective way of building knowledge (Johnson et al., 2006) and knowledge is a foundation and building block of creative ideas (Muñoz-Pascual \& Galende, 2017). The information exchange among the members can be characterized by the consultation, questioning, seeking information $\&$ feedback, and discussing work related problem to find solutions (Edmondson, 1999). Put it simply, information exchange is a process of giving and receiving work related 
information. De-Dreu et al. (2008) argued that team goal orientation is a strategy by which teams achieve goals within the organization, which compel them to share information as the work of all the team members is interdependent (if one fails all will fail). Therefore, one of the dimensions of goal orientation, i.e., goal striving leads to the exchange of information among the team members (Chen, Mathieu, \& Bliese, 2004). The team goal orientation also reflects the complete understanding of the team task for each member and to get the whole information team members share information among themselves (Bunderson \& Sutcliffe, 2003; Gong \& Fan, 2006).

$\mathrm{H}_{1}$ : Team goal orientation is positively associated with information exchange among the team members.

\subsection{Information exchange and creativity}

The team outcomes mainly depend on the level of information exchange among the members. Studies (e.g., Gong et al., 2012; Mesmer-Magnus \& DeChurch, 2009) concluded that knowledge sharing is the centerpiece of idea generation (creativity). The literature on creativity and information exchange suggests that through knowledge sharing employees connect their idea with the ideas of other employees, which help them craft new knowledge (Kogut \& Zander, 1993; Nahapiet \& Ghoshal, 1998). Other researchers have suggested that exchange of information gives birth to product innovation, especially in the $R \& D$ teams (Smith et al., 2005). Innovation is different from creativity as it is the implementation of the creative ideas; still the foundation of innovation is creativity (Bilal et al., 2018). By sharing information the team members sharpen their competence as well as bring new insight to their other members in a team. The pool of information which is accumulated in the process of information exchange help employees generate new and unique ideas for a better product or process development (Shin et al., 2012). Individuals learn from each other (Bandura, 1986; Sanford, 2017) and the information obtained from other people makes a foundation for the generation of new ideas (Amabile, 2017). The literature and the theoretical understanding of the relation between information exchange and creativity guides us to develop our hypothesis:

$\mathrm{H}_{2}$ : Information exchange among team members impacts team creativity.

$\mathrm{H}_{3}$ : Information exchange among team members mediates the relationship between goal orientation and organizational innovation.

\subsection{Creativity and innovation}

Research on creativity and innovation supported that creativity is the stepping stone for an organization. One of the landmark studies by Clegg et al. (2002) found 
that there is a positive relationship between idea generation (creativity) and idea implementation (Innovation). In another study West (2002) argued that the connection between the creativity and innovation is tightly coupled. Creativity is defined as the novel, unique and useful idea, while the innovation is the practical implementation of these ideas (Amabile, 1989); therefore, both novelty and the usefulness of ideas is a requirement of creativity. In this regard the implementation part may be compromised due to the too much novelty of the idea negatively impacts its practicality (Bear, 2012). The frequency of idea generated has a positive impact on innovation. When a large number of ideas are generated by the employees, it will add to the total idea bucket of the organization and innovation will be easy (Perry-Smith \& Mannucci, 2017). Therefore, it is hypothesized that:

$\mathrm{H}_{4}$ : Team creativity has a positive association with organizational innovation.

$\mathrm{H}_{5}$ : Team creativity mediates the relationship between information exchange and organizational innovation.

Based on the discussion on Hypothesis 3 and 5 another hypothesis (serial mediation) has been derived that:

$\mathrm{H}_{6}$ : Information exchange and team creativity mediate that relationship between team goal orientation and organizational innovation.

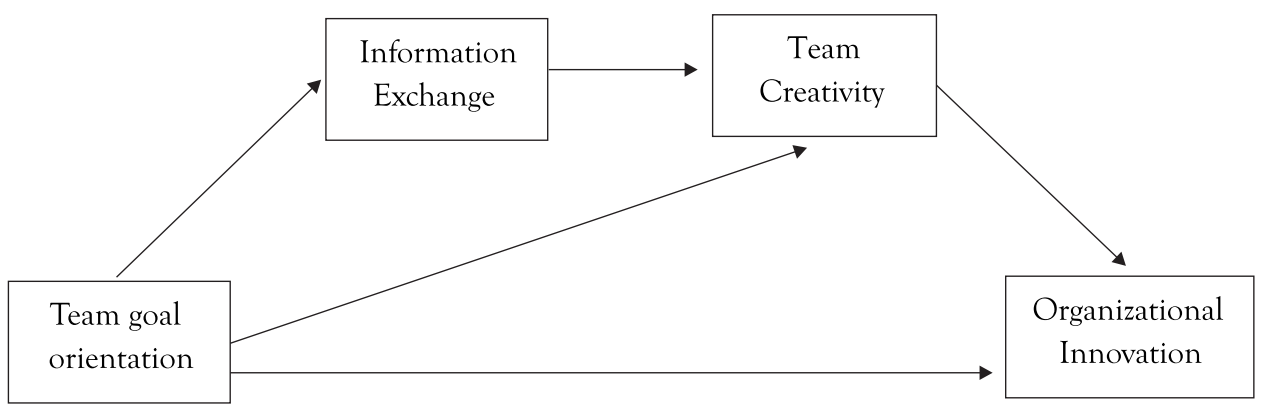

Figure 1: Theoretical Framework

\section{Research Method}

The data were collected from 70 teams (involved in ad making) of the advertising industry in Pakistan. The Sample frame consists of 132 advertising agencies from three cities of Pakistan, i.e., Islamabad, Lahore and Karachi. The criterion for inclusion was that the selected companies must be in business and making at least one ad a month from last 12 months. The free consent was obtained and teams were contacted for data collection. A questionnaire was used for data collection from the employees. A total of 436 filled questionnaires were returned out of 900 questionnaires distributed 
(response rate of 48\%). The participation was voluntary and the data confidentiality was assured. The sample characteristics are shown in Table 1.

Table 1: Sample Characteristics

\begin{tabular}{|c|c|}
\hline \multicolumn{2}{|c|}{ Gender } \\
\hline & Frequency \\
\hline Male & 189 \\
\hline Female & 247 \\
\hline \multicolumn{2}{|c|}{ Age } \\
\hline $26-35$ years old & 91 \\
\hline $36-45$ years old & 224 \\
\hline $46+$ years old & 121 \\
\hline & Experience (Working in teams) \\
\hline $1-5$ years & 96 \\
\hline $6-10$ years & 231 \\
\hline $10+$ years & 109 \\
\hline
\end{tabular}

\subsection{Measuring instrument}

The items in the survey questionnaire were adapted from the previous literature. The reason for adapting the scales from previous literature was twofold. First, the scales were used by a number of studies in different organizational settings. Second, the reliability of the adapted scales was adequate in the previous literature. For team goal orientation VandeWalle's (1997) was referred from which 5 items $(\alpha=0.778)$ were used; the same items were also used in the previous studies (Chan, 1998; Chen, Mathieu, \& Bliese, 2004). For information exchange the scale of Youndt, Subramaniam, and Snell (2004) was referred and four items $(\alpha=0.889)$ were selected for the measurement. Team creativity measurement scale was adapted from Zhou's (2008) and Amabile's (1987). Four items from Zhou's (2008) and six items from Amabile's (1987) were studied out of which 6 items were selected for the data collection $(\alpha=$ 0.779). For the organizational innovation, Zhou and George's (2001) 8-items scale was referred. All eight items were selected and used for the data collection $(\alpha=0.717)$. For all the variables 5 -point Likert Scale was used, ranging from $1=$ strongly disagree to 5 = strongly agree). The data were analyzed statistically using SPSS, 20. The Pearson's correlation and regression were applied for hypothesis testing. For the mediation analysis Hayes (2013) MEDTHREE analysis was used, which is considered to be the 
most sophisticated method of serial mediation available today.

\subsection{Data analysis}

There are two types of hypotheses of the study, i.e., direct hypotheses and indirect hypotheses. Primarily the descriptive statistics and frequencies were calculated in order to get the feel of the data. To test the direct hypotheses, regression analysis using bootstrapping method is used. For the analysis of simple and serial mediation the process suggested by Hayes (2013) is applied. The MEDTHREE analysis (model 6) by Hayes (2013) is supposed to be the most sophisticated method available for serial mediation. Therefore, the MEDTHREE analysis is used to test the mediation hypothesis to answer the central research questions of the study.

\section{Results and Findings}

Table 2, shows the descriptive statics and the correlation among variables. The correlation test was applied to measure the strength and direction of the relationship between variables of the study. The value for team goal orientation $(\mathrm{M}=3.14, \mathrm{SD}=$ $0.81)$, for information exchange $(M=2.94, S D=0.57)$, for team creativity $(M=3.11$, $\mathrm{SD}=0.70)$, and for organizational innovation $(\mathrm{M}=3.00, \mathrm{SD}=0.55)$.

Table 2: Descriptive Statistics and Correlation

\begin{tabular}{|c|c|c|c|c|c|c|}
\hline \multicolumn{4}{|c|}{ Descriptive Statistics } & \multicolumn{4}{c|}{ Correlation } \\
\hline & Mean & SD & 1 & 2 & 3 & 4 \\
\hline 1. Team goal orientation & 3.14 & 0.81 & 1 & & & \\
\hline 2. Information exchange & 2.94 & 0.57 & $0.45^{* *}$ & 1 & & \\
\hline 3. Team creativity & 3.11 & 0.70 & $0.51^{* *}$ & $0.69^{* *}$ & 1 & \\
\hline 4. Innovation & 3.00 & 0.55 & $0.49^{* *}$ & $0.80^{* *}$ & $0.76^{* *}$ & 1 \\
\hline
\end{tabular}

**. Correlation is significant at the 0.01 level, $N=436$

The correlation matrix indicates the relationship between the different variables of the study. The team goal orientation and information exchange have moderate positive correlation $(r=0.45, p=0.00)$, showing that team goal orientation can enhance information exchange among team members. The information exchange and team creativity have a strong positive correlation $(r=0.69, p=0.00)$. The organizational Innovation was the main dependent variable of the study and the results show that team creativity and organizational innovation are highly positively correlated $(\mathrm{r}=0.76$, $p=0.00$ ). This indicates that when team creativity is enhanced, the organizational innovation is also enhanced. 
Table 3: Direct Hypotheses Testing

\begin{tabular}{|c|c|c|c|c|c|c|c|}
\hline \multicolumn{8}{|c|}{ Model 1 (Outcome = IE) } \\
\hline & $\mathrm{R}$ & $\mathrm{R}^{2}$ & MSE & $\mathrm{F}$ & df1 & df2 & $\mathrm{P}$ \\
\hline & 0.45 & 0.20 & 0.26 & 110.00 & 1 & 434 & 0.00 \\
\hline & $\beta$ & SE & $\mathrm{t}$ & $\mathrm{p}$ & LLCI & ULCI & \\
\hline TGO & 32 & 0.03 & 10.49 & 0.000 & 0.26 & 0.38 & \\
\hline \multicolumn{8}{|c|}{ Model 2 (Outcome = TC) } \\
\hline & $\mathrm{R}$ & $\mathrm{R}^{2}$ & MSE & $\mathrm{F}$ & df1 & df2 & $\mathrm{p}$ \\
\hline & 0.73 & 0.53 & 0.22 & 25.00 & 2 & 433 & 0.00 \\
\hline & $\beta$ & SE & $\mathrm{t}$ & $\mathrm{p}$ & LLCI & ULCI & \\
\hline IE & 0.7 & 0.04 & 15.83 & & 0.61 & 0.79 & \\
\hline TGO & 0.22 & 0.03 & 7.04 & & 0.16 & 0.28 & \\
\hline \multicolumn{8}{|c|}{ Model 3 (Outcome = OI) } \\
\hline & $\mathrm{R}$ & $\mathrm{R}^{2}$ & MSE & $\mathrm{F}$ & df1 & df2 & $\mathrm{P}$ \\
\hline & 0.85 & 0.72 & 0.08 & 389.18 & 3 & 432 & 0.00 \\
\hline & $\beta$ & SE & $\mathrm{t}$ & $\mathrm{p}$ & LLCI & ULCI & \\
\hline IE & 0.49 & 0.03 & 14.68 & 0.00 & 0.42 & 0.56 & \\
\hline TC & 0.29 & 0.02 & 10.00 & 0.00 & 0.23 & 0.34 & \\
\hline TGO & 0.04 & 0.02 & 2.35 & 0.01 & 0.00 & 0.08 & \\
\hline
\end{tabular}

Number of bootstrap 1000, Level of confidence 95.00

The results (see table 3) of the hypothesis 1 indicate that there is a $20 \%$ variation $\left(\mathrm{R}^{2}=0.20, \mathrm{~F}=110, \mathrm{p}=0.00\right)$ in information exchange because of team goal orientation. The results support the hypothesis $\beta=0.32, \mathrm{t}=10.49$, CI $[.26, .38]$ that team goal orientation has a positive impact on information exchange among team members. The results (table 3 ) of the hypothesis 2 indicate that there is a $53 \%$ variation $\left(\mathrm{R}^{2}=0.53, \mathrm{~F}=25, \mathrm{p}=0.00\right)$ in team creativity is because of information exchange and team goal orientation. The results support the hypothesis $\beta=0.70, t=$ 15.83, CI $[.61, .79]$ that information exchange among team members has a positive impact team creativity. The results (table 4 ) of hypothesis 3 indicate that Information exchange among team members mediates the relationship between goal orientation and organizational innovation. The results $\beta=.15, \mathrm{SE}=0.20, \mathrm{CI}[.11, .20]$ shows the indirect effect of information exchange between the relationship of team goal orientation and organizational innovation. It shows that information exchange has $51 \%$ mediation role of information exchange. 
The results (see table 3) of the hypothesis 4 indicate that there is a $29 \%$ variation $\left(\mathrm{R}^{2}=0.29, \mathrm{~F}=389.18, \mathrm{p}=0.00\right)$ in organizational innovation is because of information exchange team creativity and team goal orientation. The results support the hypothesis $\beta=0.29, \mathrm{t}=10$, CI $[.23, .34]$ that team creativity has a positive impact on organizational innovation.

Table 4: Medthree Analysis for indirect hypotheses testing

\begin{tabular}{|c|c|c|c|c|}
\hline \multicolumn{5}{|c|}{ (Total, Direct and indirect effects) } \\
\hline & Effect $(\beta)$ & Boot(SE) & LLCI & ULCI \\
\hline Total indirect effect & 0.289 & 0.028 & 0.230 & 0.340 \\
\hline M1 (information exchange) & 0.158 & 0.200 & 0.110 & 0.200 \\
\hline M2 (team creativity) & 0.064 & 0.012 & 0.043 & 0.019 \\
\hline $\begin{array}{c}\text { M1 \& M2 (information ex- } \\
\text { change and team creativity) }\end{array}$ & 0.065 & 0.009 & 0.048 & 0.087 \\
\hline
\end{tabular}

Note: Indirect effects (with bootstrap 95\% CI and standard error)

M1 = Mediator one, M2 = Mediator two

The results (see table 4) of hypothesis 5 indicate that team creativity mediates the relationship between information exchange and organizational innovation. The indirect effect hypothesis $\beta=0.06, \mathrm{SE}=.012, \mathrm{CI}[.04, .01]$ shows the indirect effect of team creativity between the relationship of team goal orientation and organizational innovation. It shows that information exchange has $21 \%$ mediation role of team creativity. The results (table 4) of hypothesis 6 indicate that information exchange and team creativity mediates the relationship between information exchange and organizational innovation. The results $\beta=0.06, \mathrm{SE}=.010, \mathrm{CI}[.04, .08]$ shows the indirect effect of team creativity and information exchange (combined indirect effect) between the relationship of team goal orientation and organizational innovation. It shows that information exchange has $22 \%$ mediation role of team creativity and information exchange (serial mediation results).

\section{Discussion}

The main findings of this study provide overall support to the framework. It was found that team goal orientation is positively associated with information exchange among the team members. Gong et al. (2011) and Johnson et al. (2006) argued that sharing of information has always been an effective way of building knowledge, which is a foundation and building block of creative ideas (Amabile, 2017; Edmondson, 1999). The team goal orientation also reflects the complete understanding of the team task for each member and to get the whole information, team members share information among themselves (Bunderson \& Sutcliffe, 2003; Gong \& Fan, 2006). 
The study also found that information exchange among team members impacts team creativity, and it also mediates the relationship between goal orientation and team creativity. The results of these hypotheses are also consistent with the previous studies. The team outcomes mainly depend on the level of information exchange among the members (Guan, Xie, \& Huan, 2018; Mehta, \& Mehta, 2018). It is also reported that the interaction among all the members can be termed as the climate of the organization, and research suggests that climate is very much responsible for the general outcomes, i.e., trust, creativity or innovation. Gong et al. (2012) suggests that individual creativity ultimately leads to team creativity, which leads to organizational innovation (Amabile, 2017).

The hypothesis that team creativity has a positive association with organizational innovation and team creativity mediates the relationship between individual creativity and organizational innovation are also accepted, and the results were consistent with the previous studies. Dong et al. (2017) asserted that research on creativity and innovation support that creativity is the stepping stone for an organizational innovation. Clegg et al. (2002) found that there is a positive relationship between idea generation (creativity) and idea implementation (innovation). When a large number of ideas will be generated by the employees, it will add to the total idea bucket of the organization and innovation will be easy (Perry-Smith \& Mannucci, 2017). The hypothesis 6 postulated that there is a serial mediation of information exchange and team creativity between the team goal orientation and organizational innovation. The results support that there team goal orientation enhance information exchange, which increases tam creativity, which ultimately leads to organizational innovation. This relationship has not been tested in Pakistani context by previous studies, which contributes towards the literature of team goal orientation, information exchange, team creativity and organizational innovation.

\subsection{Managerial and theoretical implications}

The study adds to the literature of creativity and innovation. This study theorizes and empirically examines, for the first time in Pakistani advertising agencies, the bottom-up process among goal orientation, information exchange, team creativity and organizational innovation. Furthermore, the study adds to the existing theory of team goal orientation by looking into its influence to enhance creativity and innovation in advertising agencies of Pakistan. The previous research focused on the relationship of team goal orientation with creativity (Gong et al., 2009), but the present research extends this relationship by introducing innovation as an outcome variable. Furthermore, the present study also extends the understanding of the relationship between information exchange, creativity and innovation by analyzing the 
sequential mediation model. Another theoretical contribution of this research is the validation of componential model of creativity (Amabile \& Pratt, 2016). This model suggests that to be creative, the exchange of information, new ideas and knowledge is required at the workplace. The relationship of team goal orientation and the information exchange among team members are closely related to the suggestion of componential model of creativity. As the arguments of this paper also suggest that for creativity and innovation, the team goal orientation and information exchange are necessary. Therefore, a noteworthy contribution of this research is the extension of componential model of creativity.

As creative activities are often carried out by teams, understanding team creativity is of practical importance to managers. Managers may find it useful to foster the team learning goal, and this can be done through situational factors such as assigned objectives and sharing information among the team members. For example, managers could help to develop the team learning goal by serving as role models for the team members. Moreover, they may foster the trust relationship with a team leader, thus unleashing the power of the team learning goal to facilitate information exchange and creativity.

\subsection{Limitation and future research}

This study is limited in scope that is important to mention. The respondents of the study were from the advertising agencies of Pakistan and the data was collected at one point of time. The results that come out of a cross sectional data can hardly be generalized. Therefore, it is recommended to empirically test the conceptual framework over a large/different sample of respondents for the more generalizability of the results. Although, the creative teams from advertising agencies were included for data collection, there are some other industries (fashion, software, apparel designing etc.) which are involved in the creativity and innovation. The future research can take into account such organizations' creative teams to revalidate the results. Team goal orientation has a number of other dimensions, but the present study measured it as a composite variable. The future research may examine the relationship of dimensions of team goal orientation to enhance the understanding of the studied variables. No variables were controlled for the hypothesis testing for this study; therefore, it is recommended for further studies to validate the results by controlling some demographic variables for example age, gender, education etc.

\section{References}

Amabile, T. M. (1988). A model of creativity and innovation in organizations. Research in organizational behavior, 10(1), 123-167. 
Amabile, T. M. (2017). In pursuit of everyday creativity. The Journal of Creative Behavior, 51(4), 335-337.

Amabile, T. M., \& Gryskiewicz, N. D. (1989). The creative environment scales: Work environment inventory. Creativity research journal, 2(4), 231-253.

Amabile, T. M., \& Pratt, M. G. (2016). The dynamic componential model of creativity and innovation in organizations: Making progress, making meaning. Research in Organizational Behavior, 36(1), 157-183.

Amabile, T., \& Gryskiewicz, S. S. (1987). Creativity in the RËD laboratory. Center for Creative Leadership.

Antonietti, A., \& Colombo, B. (2017). Creativity in advertisement: how advertisements strike people-a critical discussion of the role of original ideas and background music. In Research Handbook of Innovation and Creativity for Marketing Management. Edward Elgar Publishing.

Bandura, A. (1989). Human agency in social cognitive theory. American psychologist, 44(9), 1175-1184.

Bilal, A., \& Ahmad, H. M. (2015). Team Goal Orientation through Information Exchange Inducement, Creativity and Innovation; with Technology and Trust in Leader as Moderators. Global Management Journal for Academic E⿱ Corporate Studies, 5(2), 123-134.

Bilal, A., Ahmad, H. M., \& Majid, F. (2018). How Formalization Impedes Employee Creativity and Organizational Innovation: A Case of Advertising Agencies in Pakistan. NUML International Journal of Business $\mathcal{E}$ Management 13(1), 66-78

Hayes, A. F. (2013). Introduction to Mediation, Moderation, and Conditional Process Analysis: A Regression-Based Approach. New York, NY: The Guilford Press. Journal of Educational Measurement, 51(3), 335-337.

Bunderson, J. S., \& Sutcliffe, K. M. (2003). Management team learning orientation and business unit performance. Journal of Applied Psychology, 88(3), 552-560.

Chan, D. (1998). Functional relations among constructs in the same content domain at different levels of analysis: A typology of composition models. Journal of applied psychology, 83(2), 234-246.

Chen, G., Mathieu, J. E., \& Bliese, P. D. (2004). A framework for conducting multilevel construct validation. Research in multilevel issues: Multilevel issues in organizational behavior and processes, 3(1), 273-303.

Clegg, C., Unsworth, K., Epitropaki, O., \& Parker, G. (2002). Implicating trust in the innovation process. Journal of Occupational and Organizational Psychology, 75(4), 409-422.

Cunado, D., Nixon, M. S., \& Carter, J. N. (2003). Automatic extraction and description of human gait models for recognition purposes. Computer Vision and Image Understanding, 90(1), 1-41.

De Dreu, C. K., Baas, M., \& Nijstad, B. A. (2008). Hedonic tone and activation level in the mood-creativity link: toward a dual pathway to creativity model. Journal of personality and social psychology, 94(5), 739-756.

Dong, Y., Bartol, K. M., Zhang, Z. X., \& Li, C. (2017). Enhancing employee creativity via individual 
skill development and team knowledge sharing: Influences of dual-focused transformational leadership. Journal of Organizational Behavior, 38(3), 439-458.

Edmondson, A. (1999). Psychological safety and learning behavior in work teams. Administrative science quarterly, 44(2), 350-383.

Gong, Y., \& Fan, J. (2006). Longitudinal examination of the role of goal orientation in cross-cultural adjustment. Journal of Applied Psychology, 91(1), 176-184.

Gong, Y., Cheung, S. Y., Wang, M., \& Huang, J. C. (2012). Unfolding the proactive process for creativity integration of the employee proactivity, information exchange, and psychological safety perspectives. Journal of Management, 38(5), 1611-1633.

Guan, X. H., Xie, L., \& Huan, T. C. (2018). Customer knowledge sharing, creativity and value co-creation: A triad model of hotels, corporate sales employees and their customers. International Journal of Contemporary Hospitality Management, 30(2), 961-979.

Gully, S. M., \& Phillips, J. M. (2005). A multilevel application of learning and performance orientations to individual, group, and organizational outcomes. Research in personnel and human resources management, 24(1), 1-51.

Hirst, G., Van Knippenberg, D., Chen, C. H., \& Sacramento, C. A. (2011). How does bureaucracy impact individual creativity? A cross-level investigation of team contextual influences on goal orientation-creativity relationships. Academy of Management Journal, 54(3), 624-641.

Johnson, M. D., Hollenbeck, J. R., Humphrey, S. E., Ilgen, D. R., Jundt, D., \& Meyer, C. J. (2006). Cutthroat cooperation: Asymmetrical adaptation to changes in team reward structures. Academy of Management Journal, 49(1), 103-119.

Kogut, B., \& Zander, U. (1993). Knowledge of the firm and the evolutionary theory of the multinational corporation. Journal of international business studies, 24(4), 625-645.

Kozlowski, S. W. J., \& Klein, K. J. (2000). A multilevel approach to theory and research in organizations: Contextual, temporal, and emergent processes. In K. J. Klein \& S. W. J. Koslowski (Eds.), Multilevel Theory, research, and methods in organizations: 3-90. San Francisco: Jossey Bass.

Levitt, T. (1963). Creativity is not enough. Harvard Business Review, 41(3): 72-83.

Liu, D., Gong, Y., Zhou, J., \& Huang, J. C. (2017). Human resource systems, employee creativity, and firm innovation: The moderating role of firm ownership. Academy of Management Journal, 60(3), 1164-1188.

Lu, J. G., Hafenbrack, A. C., Eastwick, P. W., Wang, D. J., Maddux, W. W., \& Galinsky, A. D. (2017). "Going out" of the box: Close intercultural friendships and romantic relationships spark creativity, workplace innovation, and entrepreneurship. Journal of Applied Psychology, 102(7), 1091-1108.

Mehta, A., \& Mehta, N. (2018). Knowledge integration and team effectiveness: a team goal orientation 
approach. Decision Sciences, 49(3), 445-486.

Mesmer-Magnus, J. R., \& DeChurch, L. A. (2009). Information sharing and team performance: a meta-analysis. Journal of Applied Psychology, 94(2), 535-546.

Muñoz-Pascual, L., \& Galende, J. (2017). The impact of knowledge and motivation management on creativity: Employees of innovative Spanish companies. Employee relations, 39(5), 732-752.

Nahapiet, J., \& Ghoshal, S. (1998). Social capital, intellectual capital, and the organizational advantage. Academy of management review, 23(2), 242-266.

Oldham, G. R., \& Cummings, A. (1996). Employee creativity: Personal and contextual factors at work. Academy of management journal, 39(3), 607-634.

Perry-Smith, J. E., \& Mannucci, P. V. (2017). From creativity to innovation: The social network drivers of the four phases of the idea journey. Academy of Management Review, 42(1), 53-79.

Perry-Smith, J. E., \& Mannucci, P. V. (2017). From creativity to innovation: The social network drivers of the four phases of the idea journey. Academy of Management Review, 42(1), 53-79.

Ramos, M. A. W., Figueiredo, P. S., \& Pereira-Guizzo, C. (2018). Antecedents of innovation in industry: The impact of work environment factors on creative performance. Innovation $\mathcal{E}$ Management Review, 15(3), 269-285.

Rousseau, D. M. (1985). Issues of level in organizational research: Multi-level and cross-level perspectives. Research in organizational behavior, 7(1), 1-37.

Sanford, N. (2017). Self and society: Social change and individual development. Routledge.

Schumpeter, J. (1942). Creative destruction. Capitalism, socialism and democracy, 82(5), 82-85.

Simonton, D. K. (2018). Defining Creativity: Don't We Also Need to Define What Is Not Creative?. The Journal of Creative Behavior, 52(1), 80-90.

Smith, K. G., Collins, C. J., \& Clark, K. D. (2005). Existing knowledge, knowledge creation capability, and the rate of new product introduction in high-technology firms. Academy of Management Journal, 48(2), 346-357.

Taylor, R. E., Hoy, M. G., \& Haley, E. (1996). How French advertising professionals develop creative strategy. Journal of Advertising, 25(1), 1-14.

Van Knippenberg, D., De Dreu, C. K., \& Homan, A. C. (2004). Work group diversity and group performance: an integrative model and research agenda. Journal of applied psychology, 89(6), 1008-1022.

VandeWalle, D. (1997). Development and validation of a work domain goal orientation instrument. Educational and Psychological Measurement, 57(6), 995-1015.

West, M. A. (2002). Sparkling fountains or stagnant ponds: An integrative model of creativity and innovation implementation in work groups. Applied Psychology, 51(3), 355-387. 
Youndt, M. A., Subramaniam, M., \& Snell, S. A. (2004). Intellectual Capital Profiles: An Examination of Investments and Returns. Journal of Management studies, 41(2), 335-361.

Zhou, J., \& George, J. M. (2001). When job dissatisfaction leads to creativity: Encouraging the expression of voice. Academy of Management journal, 44(4), 682-696.

Zhou, J., \& Shalley, C. E. (2008). Expanding the scope and impact of organizational creativity research. Handbook of organizational creativity, 28(1), 125-147. 